\title{
Extraordinary rates of transition metal ion-mediated ribozyme catalysis
}

\author{
MANAMI ROYCHOWDHURY-SAHA ${ }^{1}$ and DONALD H. BURKE ${ }^{2}$ \\ ${ }^{1}$ Department of Chemistry, Indiana University, Bloomington, Indiana 47405, USA \\ ${ }^{2}$ Department of Molecular Microbiology \& Immunology, University of Missouri School of Medicine, Columbia, Missouri 65211, USA
}

\begin{abstract}
In pre-steady-state, fast-quench kinetic analysis, the tertiary-stabilized hammerhead ribozyme "RzB" cleaves its substrate RNA with maximal measured $k_{\text {obs }}$ values of $\sim 3000 \mathrm{~min}^{-1}$ in $1 \mathrm{mM} \mathrm{Mn}^{2+}$ and $\sim 780 \mathrm{~min}^{-1}$ in $1 \mathrm{mM} \mathrm{Mg}^{2+}$ at $37^{\circ} \mathrm{C}(\mathrm{pH} 7.4)$. Apparent pKa for the catalytic general base is $\sim 7.8-8.5$, independent of the corresponding metal hydrate pKa, suggesting potential involvement of a nucleobase as general base as suggested previously from nucleobase substitution studies. The $\mathrm{pH}$-rate profile is bell-shaped for $\mathrm{Cd}^{2+}$, for which the general catalytic acid has a pKa of $7.3 \pm 0.1$. Simulations of the pH-rate relation suggest a pKa for the general catalytic acid to be $\sim 9.5$ in $\mathrm{Mn}^{2+}$ and $>9.5$ in $\mathrm{Mg}^{2+}$. The acid pKa's follow the trend in the pKa of the hydrated metal ions but are displaced by $\sim 1-2 \mathrm{pH}$ units in the presence of $\mathrm{Cd}^{2+}$ and $\mathrm{Mn}^{2+}$. One possible explanation for this trend is direct metal ion coordination with a nucleobase, which then acts as general acid.
\end{abstract}

Keywords: acid-base; divalent ions; hammerhead ribozyme; ribozyme kinetics

\section{INTRODUCTION}

Most natural ribozymes catalyze phosphate-group transfer or peptide-bond formation (Takagi et al. 2001; Fedor and Williamson 2005). The small ( 40-90 nucleotides [nt]), nucleolytic ribozymes - hairpin, hammerhead, hepatitis delta virus (HDV), Varkud satellite (VS), and $g \operatorname{lmS}$ - generate $5^{\prime}$-hydroxyl and $2^{\prime}, 3^{\prime}$-cyclic phosphate termini because they utilize the adjacent $2^{\prime}$ hydroxyl as nucleophile in their cleavage mechanisms. Recent studies show that divalent metal ions can be dispensed with for several of the ribozymes. For example, in hammerhead ribozyme HH16.1, divalent metal ions can be replaced with high concentrations of monovalent ions, but reaction rates are decreased by 25 -fold (Murray et al. 1998). For catalysis by the VS ribozyme (Murray et al. 1998; sequence from Guo and Collins $1995)$ in the presence of $\mathrm{Li}^{+}$and $\mathrm{Mg}^{2+}$ together, a greater reaction rate was measured than when the same reaction was carried out in $\mathrm{Mg}^{2+}$ alone. For hairpin ribozymes, neither cleavage nor ligation requires a divalent metal ion

Reprint requests to: Donald H. Burke, Department of Molecular Microbiology \& Immunology, University of Missouri School of Medicine, 471h Life Sciences Center, 1201 E. Rollins Drive, Columbia, MO 652117310, USA; e-mail: burkedh@missouri.edu; fax: (573) 884-9676.

Abbreviations: HHRz, hammerhead ribozyme; nt, nucleotides, TSMtertiary stabilizing motif.

Article published online ahead of print. Article and publication date are at http://www.rnajournal.org/cgi/doi/10.1261/rna.128906.
(Nesbitt et al. 1997). The inference drawn from such results is that the divalent ions act via "delocalized" or nonspecific interactions to stabilize the functional fold of the molecule for these ribozymes.

The hammerhead ribozyme (HHRz) catalyzes site-specific RNA cleavage and ligation during the replication cycle of some plant viral satellite RNAs. While there is a wealth of information about the structure, sequence requirements, mechanism, and biotechnology applications of hammerhead ribozymes, many questions remain regarding the molecular basis for HHRz reactivity. The minimal structure consists of three helices that intersect at a conserved catalytic core of 11 nt. Crystallographic and solution studies reveal a Y-shaped dominant conformation (Pley et al. 1994; Tuschl et al. 1994; Scott et al. 1995; Penedo et al. 2004). Under standard in vitro assay conditions $\left(10 \mathrm{mM} \mathrm{Mg}^{2+}\right)$, a well-behaved, minimal hammerhead ribozyme can be expected to cleave its substrate at a rate of $\sim 1 \mathrm{~min}^{-1}$. These same ribozymes show poor intracellular activity due to their requirement for high concentrations of divalent metal ions. Recent studies highlighted the importance of peripheral sequences in the natural and engineered HHRzs for their improved in vitro activity under physiological $\mathrm{Mg}^{2+}$ conditions $(<2 \mathrm{mM})$ and for their activity inside cells (De la Pena et al. 2003; Khvorova et al. 2003; Saksmerprome et al. 2004; Yen et al. 2004). Natural hammerhead ribozyme from schistosomes have shown exceptional cleavage rates $\left(\sim 870 \mathrm{~min}^{-1}\right)$ when assayed in vitro under 
reaction conditions that included very high $\mathrm{Mg}^{2+}$ concentrations (200 mM) and high pH (8.5) (Canny et al. 2004).

We previously described artificial tertiary stabilizing motifs (TSMs) in the context of trans-cleaving versions of natural $\mathrm{HHRz}$ derived from peach latent mosaic viroid (PLMVd) and from Schistosoma mansoni (Saksmerprome et al. 2004). In the present work, we have probed the catalytic mechanism of one of these artificial TSM-HHRzs, designated RzB (Fig. 1A) by examining the metal and $\mathrm{pH}$ dependence for self-cleavage of the ribozyme. Very high rates in the range 100-3000 $\mathrm{min}^{-1}$ are observed in submillimolar divalent ions, but only when the TSM is kept intact. This structural requirement highlights the importance of the tertiary interactions in enhancing the activity of RzB in low metal ion concentrations. The $\mathrm{pH}$ dependence of the reaction as a function of metal ion suggests a nucleobasecatalyzed acid-base mechanism, consistent with recent nucleobase substitution studies that supported G8 and G12 as general acid-base catalysts in the cleavage mechanism of a minimal hammerhead ribozyme (Han and Burke 2005).

\section{RESULTS}

\section{Millisecond timescale cleavage in low $\mathbf{M g}^{2+}$}

The cis-cleaving $\mathrm{HHRz}$ from PLMVd exhibits rapid cleavage $\left(k_{\mathrm{obs}}>2 \mathrm{~min}^{-1}\right)$ at submillimolar concentrations of magnesium, similar to the behavior observed for other naturally occurring hammerhead ribozymes (Khvorova et al. 2003; Canny et al. 2004; Saksmerprome et al. 2004). Upon extended incubation, the reaction approached 70\% completion (Saksmerprome et al. 2004). Ribozyme RzB (Fig. 1A) is a trans-cleaving derivative of the PLMVd hammerhead ribozyme, in which loop II differs from the natural sequence by the introduction of a single A-to-G mutation, and the structural context of the tertiary contact is altered by converting the natural terminal loop I into a bulge within the ribozyme strand of stem I of RzB (Saksmerprome et al. 2004). Previous studies of this ribozyme using manual mixing methods demonstrated that RzB cleaves its target rapidly at submillimolar concentrations of magnesium at $37^{\circ} \mathrm{C}$ ( $\mathrm{pH} 7.4)$. Furthermore, the reaction goes to a greater extent $(>90 \%)$ than the parent molecule from which it was derived (Saksmerprome et al. 2004).

In manually controlled reactions in $1 \mathrm{mM} \mathrm{Mg}^{2+}$, RzB cleaves $>80 \%$ of its substrate in the first $30 \mathrm{sec}$, while a control ribozyme RzB0 lacking tertiary stabilizing structural elements (UAA bulge in stem I is deleted) cleaved $<2 \%$ of its substrate during this time (Fig. 1B). Therefore, to access the very earliest events in the reactions catalyzed by ribozyme $\mathrm{RzB}$, initial cleavage rates were remeasured in rapid-quench reactions. Catalytic activity is vigorous on a millisecond timescale, with $>10 \%$ substrate cleaved within the first $0.5 \mathrm{sec}$ in $10 \mathrm{mM} \mathrm{Mg}^{2+}$ and $~ 5 \%$ in $1 \mathrm{mM} \mathrm{Mg}^{2+}$ (Fig. 1C). Curve fitting with a singleexponential equation satisfactorily describes the kinetic behavior during
FIGURE 1. Cleavage kinetics. (A) Predicted structures of RzB and RzB0. Red, catalytic core; blue, substrate strand; purple, ribozyme strand loop II and Bulge I; green arrow, cleavage site. The A-to-G mutation that arose during selection of RzB (11) is indicated within loop II. $(B)$ Kinetic profile of $\mathrm{RzB}$ (red circles) and $\mathrm{RzB} 0$ (blue squares) in $1 \mathrm{mM} \mathrm{Mg}^{2+}$ at $37^{\circ} \mathrm{C}(\mathrm{pH} 7.4$ ). (C) Millisecond kinetics of RzB at $37^{\circ} \mathrm{C}(\mathrm{pH} 7.4)$ in $1 \mathrm{mM} \mathrm{Mg}^{2+}$ (red circles), $2 \mathrm{mM} \mathrm{Mg}^{2+}$ (blue squares), $4 \mathrm{mM} \mathrm{Mg}^{2+}$ (pink diamonds), $5 \mathrm{mM} \mathrm{Mg}^{2+}$ (black squares), $10 \mathrm{mM} \mathrm{Mg}^{2+}$ (green plus signs), and $20 \mathrm{mM} \mathrm{Mg}{ }^{2+}$ (cyan triangles). (D) $\mathrm{Mg}^{2+}$-binding profiles of RzB (red circles) and RzB0 (blue circles). Reported error is the uncertainty of the fit of each plot as calculated in KaleidaGraph 3.5. Reactions for RzB in sub-millimolar magnesium and all data for RzB0 were manually controlled (Supplemental Fig. 1A). 
the initial $\sim 0.5 \mathrm{sec}$ (Fig. 1C). Increasing $\mathrm{Mg}^{2+}$ concentration yields an increase in the apparent first-order rate constant during this early phase until it saturates by $10 \mathrm{mM}$ $\mathrm{Mg}^{2+}\left(k_{\max }=376 \pm 21 \mathrm{~min}^{-1}\right)$ (Fig. 1D). The kinetic profile in the presence of $\mathrm{Mg}^{2+}$ is multiphasic when evaluated over the full time course, and cleavage during the second phase of the reaction (beyond $0.5 \mathrm{sec}$ ) is not yet saturated at $10 \mathrm{mM} \mathrm{Mg}^{2+}$ (data not shown). The kinetic behavior of the control ribozyme, RzB0, was also biphasic at elevated $\mathrm{Mg}^{2+}$ concentrations (10-50 mM) (Supplemental Fig. 1B), and approaches saturation in the first phase at $50 \mathrm{mM} \mathrm{Mg}^{2+}\left(k_{\max }=7.5 \pm 0.3 \mathrm{~min}^{-1}\right)$ (Fig. 1D).

The initial rate data for both ribozymes can be fit to a twostate model for $\mathrm{Mg}^{2+}$ binding, with Hill coefficients of $2.0 \pm$ 0.3 for RzB and $2.2 \pm 0.1$ for RzB0 (Fig. 1D). The similarity in the Hill coefficients suggests a similar degree of cooperativity in $\mathrm{Mg}^{2+}$ binding by both constructs. Importantly, the concentration at which cleavage rate is half maximal, $\left[\mathrm{Mg}^{2+}\right]_{1 / 2}$, decreases from $11.7 \mathrm{mM}$ for RzB0 to only 1.9 $\mathrm{mM}$ for RzB. Interestingly, the $\left[\mathrm{Mg}^{2+}\right]_{1 / 2}$ value for $\mathrm{RzB}$ is less than one-twentieth that observed for the natural Schistosoma hammerhead ribozyme ( $\sim 40 \mathrm{mM}$ ) (Canny et al. 2004).

\section{Rapid cleavage in transition metals}

Previous studies of substrate cleavage by minimal hammerhead ribozymes demonstrated that $10 \mathrm{mM}$ transition metals only moderately supported catalysis, yielding cleavage rates of $<0.25 \mathrm{~min}^{-1}$ (Dahm and Uhlenbeck 1991; Dahm et al. 1993). In contrast, in the present study, substrate cleavage by hammerhead ribozyme RzB in each of several different transition metal ions (1 $\mathrm{mM})$ gave cleavage rates of $>100 \mathrm{~min}^{-1}$ at $37^{\circ} \mathrm{C}(\mathrm{pH} 7.4)$ (Fig. 2A,B;
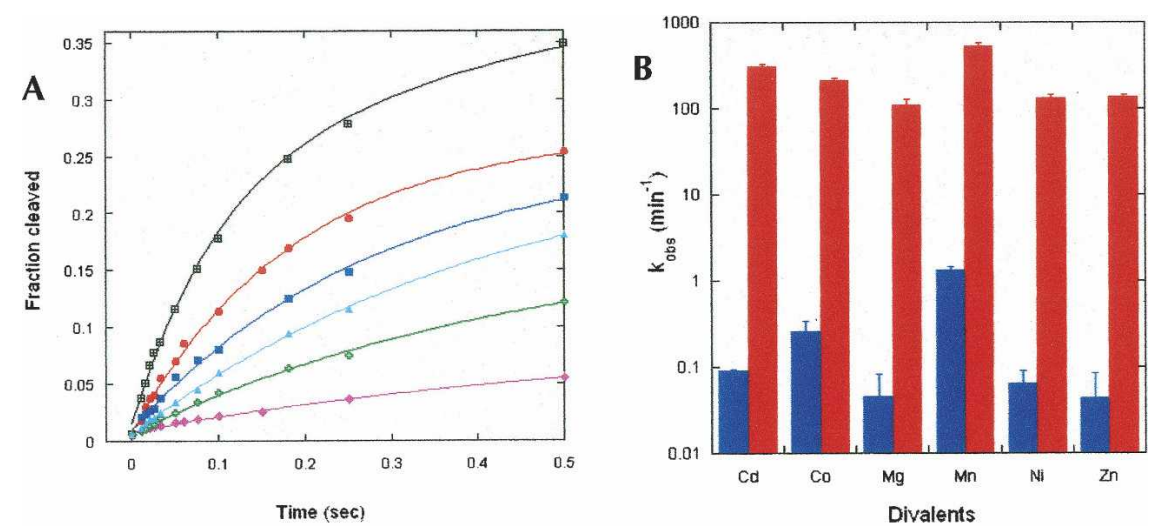

FIGURE 2. Metal ion dependence of RzB cleavage on a millisecond timescale. (A) Reactions carried out at $37^{\circ} \mathrm{C}(\mathrm{pH} 7.4)$ in $1 \mathrm{mM} \mathrm{Mg}^{2+}$ (pink diamonds), $1 \mathrm{mM} \mathrm{Ni}^{2+}$ (green plus signs), $1 \mathrm{mM} \mathrm{Zn}^{2+}$ (aqua triangles), $1 \mathrm{mM} \mathrm{Co}{ }^{2+}$ (blue squares), $1 \mathrm{mM} \mathrm{Cd}^{2+}$ (red circles), and $1 \mathrm{mM}$ $\mathrm{Mn}^{2+}$ (black squares). Calculation of $k_{\text {obs }}$ was achieved by fitting each time course (through the first $0.5 \mathrm{sec}$ ) to a single-exponential equation, except the one for $\mathrm{Mn}^{2+}$, for which a doubleexponential equation was used. (B) Bar graph of $\mathrm{k}_{\mathrm{obs}}$ values for $\mathrm{RzB}$ (red) and RzB0 (blue). Reported error for RzB is the uncertainty of the fit of each plot and for RzB0 (Supplemental Fig. 2B) was calculated from duplicate data sets.
Supplemental Fig. 2A). The greatest cleavage rates were observed for $1 \mathrm{mM} \mathrm{Mn}{ }^{2+}\left(537 \pm 57 \mathrm{~min}^{-1}\right)$. Control ribozyme RzB0 behaved similarly to minimal ribozymes in previous studies (Dahm et al. 1993), yielding cleavage rates in the range of $0.04-1.34 \mathrm{~min}^{-1}$ depending on the divalent ion (Fig. 2B; Supplemental Fig. 2B). Tertiary stabilization therefore confers $>400$-fold activation relative to minimal hammerhead ribozymes at $1 \mathrm{mM}$ transition metal ions.

\section{Cleavage in alkaline earth metal ions}

All of the transition metal ions tested support higher catalytic rates than those obtained in $\mathrm{Mg}^{2+}$ (Fig. 2A,B; Supplemental Fig. 2A). In contrast, the cleavage rates obtained in the group IIA (alkaline earth) metals were all much lower than those obtained in $\mathrm{Mg}^{2+}$, ranging from $0.072 \pm 0.002$ in $1 \mathrm{mM} \mathrm{Ba}^{2+}$ to $0.46 \pm 0.02$ in $1 \mathrm{mM} \mathrm{Ca}^{2+}$ (Fig. 3A). Two major differences between the alkaline earth metals and the transition metals are the absence of d-orbital electrons and the larger ionic radii in the alkaline earth metals. The absence of d-orbital electrons affects the $\mathrm{pKa}$ of the metal ion hydrate, while the larger ionic radius decreases the metal's ionic potential-defined as the ratio of the formal charge to the ionic radius of the ion. The latter effect decreases the net Coulombic interactions of the metal with neighboring ions through electrostatic interactions. No correlation was observed between activity and ionic potential for either alkaline earths or transition metals (data not shown). However, there was an inverse correlation between $\mathrm{pKa}$ of group IIA metal ion hydrates with RzB cleavage activity at $\mathrm{pH} 7.4$ (slope of $-1.4, R^{2}=0.92$ ) (Fig. $3 \mathrm{~A})$. A slope of $-0.95, R^{2}=0.86$, was previously observed for a similar plot of $\mathrm{pKa}$ of the metal ion hydroxide vs. $\log \left(k_{\text {obs }}\right)$ for a minimal hammerhead ribozyme (Fig. 3A; Dahm and Uhlenbeck 1991; Dahm et al. 1993). The negative slopes in the above plots could be explained either by the reduced concentration of the Brønsted base form of the metal hydrate ion, or by the known reduction in Lewis acidity (inversely related to $\mathrm{pKa}$ ) of the heavier metals within a group in the periodic table. The $\mathrm{pH}$ dependence of the cleavage reaction (below) support the latter model.

\section{Dependence of rate on $\mathrm{pH}$}

To determine whether the rapid cleavage observed in transition metals is linked to their $\mathrm{pKa}$ values, we examined the $\mathrm{pH}$ dependence of $\mathrm{RzB}$ activity in three divalent ions whose $\mathrm{pKa}$ values differ from each other by $\sim 1$ unit: 11.4 for $\mathrm{Mg}^{2+}, 10.6$ for $\mathrm{Mn}^{2+}$ and 9.0 for 

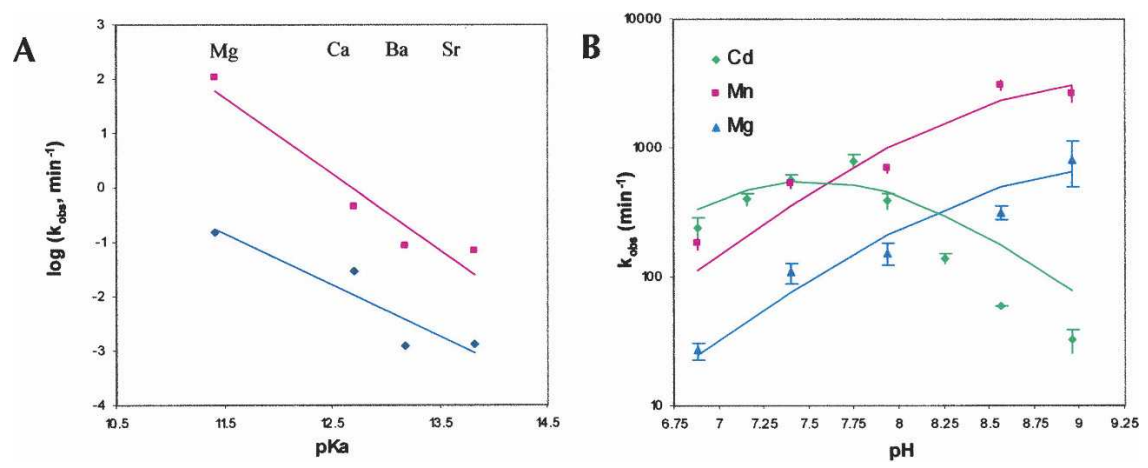

FIGURE 3. RzB cleavage rate dependence on group IIA metal ions and pH. (A) Hammerhead cleavage rates in group IIA metals as a function of their pKa. RzB measurements were made in $1 \mathrm{mM}$ metal ions at $37^{\circ} \mathrm{C}$ ( $\mathrm{pH} 7.4$ ) (pink squares; fit to linearity, $R^{2}=0.92$ ), and minimal hammerhead (data taken from Dahm and Uhlenbeck 1991) data were taken in $10 \mathrm{mM}$ metal ions at $25^{\circ} \mathrm{C}$ ( $\mathrm{pH} \mathrm{7.5)} \mathrm{(indigo} \mathrm{diamonds;} \mathrm{fit} \mathrm{to} \mathrm{linearity,} R^{2}=0.86$ ). $(B) \mathrm{pH}$-rate profile of RzB at $37^{\circ} \mathrm{C}$, in $1 \mathrm{mM} \mathrm{Mg}^{2+}$ (blue triangles), $\mathrm{Mn}^{2+}$ (pink squares), or $\mathrm{Cd}^{2+}$ (green diamonds). All experiments were performed in the quench flow device, and all reactions included $10 \mu \mathrm{M}$ EDTA and $50 \mathrm{mM}$ Tris buffer at the respective $\mathrm{pH}$. Individual kinetic traces are shown in Supplemental Figure $3(A-C)$. Values for pKa were calculated using Equation 4 or Equation 5 (see Materials and Methods) to be $8.5 \pm 0.2\left(k_{\max }=975 \pm 179 \mathrm{~min}^{-1}\right)$ for $\mathrm{Mg}^{2+}$ and $8.5 \pm 0.1$ $\left(k_{\max }=4380 \pm 594 \mathrm{~min}^{-1}\right)$ for $\mathrm{Mn}^{2+}$. The two pKa values for $\mathrm{Cd}^{2+}$ were calculated to be $7.8 \pm$ 0.1 and $7.3 \pm 0.1\left(k_{\max }=3870 \pm 589 \mathrm{~min}^{-1}\right)$. The interpretation given in the text assumes that the higher $\mathrm{pKa}$ value represents the general base for the reaction.

$\mathrm{Cd}^{2+}$ (Fig. 3B; Supplemental Fig. 3A-C). When substrate cleavage by $\mathrm{RzB}$ was monitored over the $\mathrm{pH}$ range of $6.88-$ 8.96 in the presence of either $1 \mathrm{mM} \mathrm{Mg}^{2+}$ or $1 \mathrm{mM} \mathrm{Mn}^{2+}$, the initial rate of cleavage increased log-linearly with $\mathrm{pH}$ with a slope of 0.78 . Such a pH-rate correlation is expected if a single proton transfer is involved in the rate-limiting step that is being monitored. Fitting the $\mathrm{pH}$ rate profile to a theoretical curve corresponding to a single proton transfer event (Bevilacqua 2003) yields pKa values close to 8.5 for both the $\mathrm{Mg}^{2+}$-dependent $(8.5 \pm 0.2)$ and the $\mathrm{Mn}^{2+}$-dependent $(8.5 \pm 0.1)$ reactions (Table 1$)$. We assign this pKa to the general base on the assumption that higher $\mathrm{pH}$ would populate the deprotonated form of this active site moiety and make it more available to abstract a proton, while acknowledging that there is intrinsic ambiguity in this assignment (Bevilacqua 2003). The fact that both reactions share a common $\mathrm{pKa}$ value that differs markedly from the pKa of the metal ion hydrates suggest that the metal ion hydrates are not acting directly as general base in these reactions. In $1 \mathrm{mM} \mathrm{Mn}^{2+}$ at $\mathrm{pH} 8.56$, ribozyme RzB achieves an unprecedented $k_{\text {obs }}$ value of $\sim 51 \mathrm{sec}^{-1}\left(3060 \pm 260 \mathrm{~min}^{-1}\right)$. Very rapid cleavage is also observed in $1 \mathrm{mM} \mathrm{Mg}^{2+}$ ( $\mathrm{pH}$ 8.96), where the cleavage rate exceeds $13 \sec ^{-1}\left(810 \pm 320 \mathrm{~min}^{-1}\right.$ at $\mathrm{pH}$ 8.96). Previous work on hammerhead and VS ribozymes reported rates as high as $600-800 \mathrm{~min}^{-1}$ in $200 \mathrm{mM}$ $\mathrm{Mg}^{2+}$ (pH 8.5) (Canny et al. 2004; Zamel et al. 2004). The rates that we obtained here for RzB were measured in much lower concentrations of divalent metal ions, yet they are as fast as, or faster than, the catalytic rates of any previously characterized ribozyme.
The $\mathrm{pH}$-rate profile of $\mathrm{RzB}$ in the presence of $\mathrm{Cd}^{2+}$ exhibits the classical bell shape indicative of two simultaneous protonation-deprotonation events taking place in the transition state (Fig. $3 \mathrm{~B})$. Such behavior is well known in protein enzymes such as ribonuclease A, where one active site histidine acts as general base to deprotonate the $2^{\prime}$ hydroxyl, and a second histidine acts as general acid to protonate the leaving group 5' hydroxyl (Raines 1998; Pinard et al. 2001). The $\mathrm{pH}$-rate profile of $\mathrm{RzB}$ in the presence of $\mathrm{Cd}^{2+}$ was therefore fit to a theoretical curve corresponding to two proton transfer events (Fig. 3B). The $\mathrm{pKa}$ of the general base (caveat vide supra) in $\mathrm{Cd}^{2+}$-activated catalysis (7.8 \pm 0.1 ) (Table 1) is again different from that of the hydrated ion, and it is similar (within fivefold hydroxide ion concentration) to the $\mathrm{pKa}$ value of the general base obtained in the presence of the other two metals. The recurrence of a common pKa value for the general base, in the presence of three different cations, support a model in which the role of the general base is played by a chemical moiety other than a hydrated metal ion, such as a nucleobase functional group.

The $\mathrm{pKa}$ of the general acid in $\mathrm{Cd}^{2+}$-activated catalysis is $7.3 \pm 0.1$, which is $1.7 \mathrm{pKa}$ units lower than the $\mathrm{pKa}$ of the metal hydrate. The $\mathrm{pH}$ activity profiles in the presence of $\mathrm{Mg}^{2+}$ and $\mathrm{Mn}^{2+}$ do not exhibit any bell-shaped features (Fig. 3B). Cleavage rates begin to plateau at high $\mathrm{pH}$ (8.56) in $\mathrm{Mn}^{2+}$, likely due to a combination of saturation of an active site residue and the beginnings of alkaline denaturation. Simulations of $\mathrm{pH}$-rate plots suggest the $\mathrm{pKa}$ of the general acid to be $>9.5$ in $\mathrm{Mg}^{2+}$ and $\sim 9.5$ in $\mathrm{Mn}^{2+}$ (data not shown). These values are difficult to confirm experimentally because nonspecific deprotonation denatures RNA at high $\mathrm{pH}(>9)$. The trend in the $\mathrm{pKa}$ value of the general acid in different metals follows the same trend as the $\mathrm{pKa}$ of the individual metal hydrates, but it is lower by $\sim 1-2 \mathrm{pH}$ units in the cases of $\mathrm{Cd}^{2+}$ and $\mathrm{Mn}^{2+}$.

\section{DISCUSSION}

Tertiary stabilization markedly affects hammerhead ribozyme kinetic behavior and metal ion sensitivity. The $\mathrm{Mg}^{2+}$ binding isotherms of RzB and RzB0 (Fig. 1D) suggest a requirement for approximately two $\mathrm{Mg}^{2+}$ ions in order to access the transition state for both ribozymes (Hill coefficients of 2 and 2.2). The large difference in observed rate constants $\left(k_{\max }=375 \mathrm{~min}^{-1}\right.$ vs. $7 \mathrm{~min}^{-1}$ at $\mathrm{pH}$ 7.4) (Fig. 1D) suggests that these two molecules may experience 
TABLE 1. Deprotonation equilibrium constants

\begin{tabular}{lccc}
\hline Metal ion & $\mathrm{pK}_{\mathrm{a} \text {, hexahydrate }}$ & $\begin{array}{c}\text { Apparent } \\
\mathrm{pK}_{\mathrm{a}} \text {, base }\end{array}$ & $\begin{array}{c}\text { Apparent } \\
\mathrm{pK}_{\mathrm{a} \text {, acid }}\end{array}$ \\
\hline $\mathrm{Mg}^{2+}$ & 11.4 & $8.5(0.2)^{\mathrm{a}}$ & $>9.5$ \\
$\mathrm{Mn}^{2+}$ & 10.6 & $8.5(0.1)^{\mathrm{a}}$ & $\sim 9.5$ \\
$\mathrm{Cd}^{2+}$ & 9.0 & $7.8(0.1)^{\mathrm{a}}$ & $7.3(0.1)^{\mathrm{a}}$ \\
\hline${ }^{\mathrm{a}}$ Calculated from curve-fitting to data in Figure 3 as described in \\
the text.
\end{tabular}

different rate-limiting steps. For example, tertiary stabilization may place RzB into a predominant conformation which is further along the reaction pathway. The ratedetermining step could then be either the chemical step itself or an active-site rearrangement of low activation energy, such as a rigid-body rotation of helix I, accompanied by alignment of the $2^{\prime}$ oxygen for in-line attack on the scissile phosphate, as previously suggested by Dunham and Scott (Dunham et al. 2003). In the case of RzB0, the slow rate may be due to an on- or off-pathway conformational change of high activation barrier, which saturates at $7.5 \pm$ $0.3 \mathrm{~min}^{-1}$ and requires much higher $\mathrm{Mg}^{2+}\left(\left[\mathrm{Mg}^{2+}\right]_{1 / 2}\right.$ $\sim 12 \mathrm{mM}$ ).

Ribozyme-catalyzed RNA cleavage requires deprotonation of the attacking 2' hydroxyl by a general base and protonation of the leaving group $5^{\prime}$ oxyanion by a general acid. The hammerhead ribozyme appears to employ both proton transfer strategies. The $\mathrm{pH}$-dependent activities in $\mathrm{Mg}^{2+}, \mathrm{Cd}^{2+}$, and $\mathrm{Mn}^{2+}$ indicate a common general base of $\mathrm{pKa} \sim 7.8-8.5$ (Table 1 ), which is distinct from the $\mathrm{pKa}$ values of all three of the metal ion hydrates. This observation would seem to rule out a model in which the decreased reactivity observed for larger divalent alkaline earth metal ions (Fig. 3A) is caused by a decrease in the concentration of the Brønsted base form; decreased Lewis acidity is the more likely explanation (see Results). It is possible that the general acids for the reactions promoted by $\mathrm{Mg}^{2+}, \mathrm{Cd}^{2+}$, and $\mathrm{Mn}^{2+}$ are provided by the corresponding metal ion hydrates and that their pKa's are lowered by the local environment. However, there is mounting evidence that small ribozymes use nucleotide bases for their catalytic chemistry (Nakano and Bevilacqua 2001; Pinard et al. 2001; Collins 2002; Jones and Strobel 2003; Nakano et al. 2003; Bevilacqua et al. 2004, 2005; Han and Burke 2005). For example, in previous studies of a minimal $\mathrm{HHRz}$ (Han and Burke 2005), simultaneous substitution of G8 and G12 with 2,6-diaminopurine (diAP) ( $\mathrm{pKa} 5.1$ vs. pKa 9.2 for $\mathrm{G}$ ) yielded a bell-shaped $\mathrm{pH}$-rate profile, implicating these two nucleobases in both proton transfer steps. Although these two Guanosine bases are 10-15 $\AA$ away from the cleavage site in ground-state crystal structures (Scott et al. 1995; Wedekind and McKay 1998; Blount and Uhlenbeck 2005), they can form an intramolecular crosslink with bases spanning the cleavage site (Heckman et al. 2005), providing evidence for a large-scale conformational change wherein G8 and G12 stack on the cleavage site bases. In RzB catalysis, the role of a general base can be fulfilled by either of the two guanosines. If the other guanosine serves as general acid, our observation that the $\mathrm{pKa}$ of the general acid varies with the metal ion used in the reaction may suggest perturbation of that guanosine's $\mathrm{pKa}$ by a direct (inner sphere) coordination of the metal ion to the nucleobase or by the close proximity of the metal ion's positive charge. The metal ion's proximity would be particularly stabilizing for the anionic form of the guanosine formed upon contributing a proton to the leaving group (general acid in the reaction) or positioned to abstract a proton from the attacking nucleophile (general base in the reaction), independent of the metal ion's pKa. Confirmation of this model awaits high-resolution structural data or alternative support.

It appears that different classes of metals promote catalysis by following different catalytic pathways. $\mathrm{Mg}^{2+}$ and the transition metals promote cleavage at higher rates by following a catalytic route involving a transition state with a low activation energy barrier. The rapid catalysis observed for the tertiary stabilized RzB in the presence of $\mathrm{Mg}^{2+}$ and the transition metals $\left(k_{\text {obs }} \gg 100 \mathrm{~min}^{-1}\right.$ in $1 \mathrm{mM}$ cations) support a special structural or catalytic role for divalent metal ions, such as participation in the chemistry step indirectly through electrostatic interaction or coordinate bond formation with the general acid, G8 or G12. Proximity of divalent ions to these nucleobases has been seen for both the natural and minimal hammerhead molecules (A9/G10.1 metal binding site) (Scott et al. 1995; Wang et al. 1999; Hunsicker and DeRose 2000; Maderia et al. 2000; Hampel and Burke 2003; Vogt et al. 2003). The slower catalysis observed in $\mathrm{Ca}^{2+}, \mathrm{Sr}^{2+}$, and $\mathrm{Ba}^{2+}$ (Fig. 3A) and in $\mathrm{Na}^{+}$, spermidine, and cobalt hexammine (M. Roychowdhury-Saha and D.H. Burke, in prep.), may reflect a high-energy barrier conformational change that accompanies acquisition of the transition state. On the other hand, because these ions cannot form strong inner sphere coordination with guanosine, the low catalytic rates that they promote may simply result from loss of a catalytic mechanism by failure of the general acid to protonate the $5^{\prime}$ oxyanion leaving group.

\section{SUPPLEMENTAL MATERIAL}

Kinetic traces of RzB and RzB0 cleavage as a function of $\mathrm{Mg}^{2+}$ concentration, kinetic traces in various divalent metal ions for RzB at 10-100 msec and for RzB0 up to $10 \mathrm{~min}$, and kinetic traces at various $\mathrm{pH}$ values for $\mathrm{RzB}$ in $1 \mathrm{mM}$ $\mathrm{Mg}^{2+}, \mathrm{Mn}^{2+}$, or $\mathrm{Cd}^{2+}$ are available upon request as Supplemental Material by sending an e-mail message containing the keyword "RNA_06_RzB_Supplementary" to the corresponding author. 


\section{MATERIALS AND METHODS}

\section{Materials}

DNA and RNA oligonucleotides were purchased from Integrated DNA Technologies; radiolabeled nucleotides, from ICN; and dNTPs, from Amersham Pharmacia. All other chemicals were purchased from Sigma-Aldrich at the highest purity grade available.

\section{Methods}

Kinetic measurements were performed under single-turnover conditions (40:1 excess ribozyme over substrate) by assembling reactive complexes from separately prepared ribozyme and substrate strands. Ribozyme strands were synthesized by in vitro transcription using T7 RNA polymerase from Ampliscribe kit following the supplier's protocol. Substrate strand was synthesized chemically by Integrated DNA Technologies, 5' radiolabeled using $\left[\gamma^{-32} \mathrm{P}\right]$ ATP and polynucleotide kinase, and gel-purified.

Unless noted otherwise, cleavage reactions were performed on a rapid quench flow device (Kintek RQF-3). Reactions were initiated by rapidly $(<0.2 \mathrm{msec})$ mixing equal volumes $(\sim 15 \mu \mathrm{L})$ of preassembled hammerhead complexes from chamber A $(2 \mu \mathrm{M}$ ribozyme strand + $50 \mathrm{nM}$ substrate strand in $50 \mathrm{mM}$ Tris. $\mathrm{HCl}$ and $10 \mu \mathrm{M}$ EDTA at $\mathrm{pH}$ 7.4) with metal ion solution from chamber $\mathrm{C}$ (metal ions at $2 \times$ final concentration in $50 \mathrm{mM}$ Tris. $\mathrm{HCl}$ and $10 \mu \mathrm{M}$ EDTA at $\mathrm{pH}$ 7.4). Each solution was equilibrated separately for $\sim 1 \mathrm{~min}$ at $37^{\circ} \mathrm{C}$ in the sample loading loops prior to mixing. Reactions were stopped with $90 \mu \mathrm{L}$ of quench solution (90\% formamide, $50 \mathrm{mM}$ EDTA, $0.005 \%$ each of xylene cyanol and bromophenol blue) supplied from chamber B. Samples corresponding to each reaction time were collected independently, electrophoresed on $15 \%$ denaturing polyacrylamide gel to separate the cleaved product band from the full-length substrate band, and exposed to a PhosphorImager screen. Band intensities were quantified by using ImageQuant software (Molecular Dynamics). The fraction cleaved $\left(F_{t}\right)$ at time $t$ was fit using KaleidaGraph 3.5 either to a single-exponential equation:

$$
F_{t}=F_{0}+\left(F_{\infty}-F_{0}\right)\left\{1-\exp \left(-k_{o b s} t\right)\right\}
$$

or to a bi-exponential equation,

$$
\begin{aligned}
F_{t}= & F_{0}+\left(F_{\infty}-F_{0}\right)\left\{1-\alpha \exp \left(-k_{o b s, 1} t\right)-(1-\alpha)\right. \\
& \left.\times \exp \left(-k_{o b s, 2} t\right)\right\}
\end{aligned}
$$

where $F_{0}$ is the zero-point correction, $F_{\infty}$ is the estimated plateau value at infinite time, $\alpha$ is the fraction of the cleaved population with a rate constant of $k_{\mathrm{obs}, 1}$, and $(1-\alpha)$ is the fraction cleaved with a rate constant of $k_{\mathrm{obs}, 2}$. Uncertainties were calculated either from curve fit or from analysis of duplicate measurements as indicated in the respective figure legends. Manually controlled cleavage reactions for times $>10 \mathrm{sec}$ were carried out under the same ribozyme-substrate complex concentrations as in quench flow experiments following the protocol as described previously (Saksmerprome et al. 2004). For kinetic traces shown in Figure 1, data were gathered to $1-2 \mathrm{sec}$. To determine initial rates, data were fit to single-exponential kinetic model (Equation 1) through
$0.5 \mathrm{sec}\left(0.25 \mathrm{sec}\right.$ in the case of $\left.20 \mathrm{mM} \mathrm{Mg}^{2+}\right)$, after which a second, slower phase became apparent. Data were fit to

$$
k_{o b s}=k_{\max }\left\{[M g]^{n} /\left([M g]^{n}+K_{D}\right)\right\}
$$

using KaleidaGraph 3.5, where $\left[\mathrm{Mg}_{1 / 2}\right]=K_{\mathrm{D}}{ }^{(1 / n)}$. In the case of $\mathrm{RzB}$, the $\mathrm{Mg}^{2+}$ binding equation was fit to $k_{\mathrm{obs}}$ values observed over the range of $0.2-10 \mathrm{mM} \mathrm{Mg}^{2+}$.

The studies of $\mathrm{pH}$ dependence were done at $37^{\circ} \mathrm{C}$ in the presence of $1 \mathrm{mM}$ divalent metal ions in $50 \mathrm{mM}$ Tris. $\mathrm{HCl}$ buffer $(\mathrm{pH} 6.88$ 8.96), $10 \mu \mathrm{M}$ EDTA. For reactions to be carried out at $\mathrm{pH}$ values higher than 8.5 , fresh $\mathrm{Mn}^{2+}$ stock solutions $(2 \mathrm{mM})$ in the $\mathrm{pH}$ buffer were prepared for each time point to minimize the formation of insoluble $\mathrm{MnO}_{2}$. These solutions were incubated at $37^{\circ} \mathrm{C}$ in the loading loop of the quench-flow apparatus for $1 \mathrm{~min}$ before the start of the reaction. Similarly, for $\mathrm{pH}$ values higher than 8.25 , fresh $\mathrm{Cd}^{2+}$ stock solutions were prepared to minimize the insoluble $\mathrm{Cd}(\mathrm{OH})_{2}$ formation. For $\mathrm{Mg}^{2+}$ and $\mathrm{Mn}^{2+}$ reactions, the data were fit to

$$
k_{o b s}=k_{\max } /\left(1+10^{(\mathrm{pKa}-\mathrm{pH})}\right)
$$

For $\mathrm{Cd}^{2+}$, the data were fit to

$$
k_{o b s}=k_{\max } /\left(1+10^{(\mathrm{pKa}-\mathrm{pH})}+10^{\left(\mathrm{pH}^{\mathrm{pKa}}{ }^{\prime}\right)}+10^{\left(\mathrm{pKa}^{\mathrm{pKa}} \mathrm{a}^{\prime}\right)}\right)
$$

\section{ACKNOWLEDGMENTS}

Venkat Gopalan and Hsin-Yue Tsai at Ohio State University helped train M.R.S. on the use of the quench flow apparatus. Sugata Roy Chowdhury provided technical assistance. The quench flow apparatus was purchased with funds from NIH grant AI062513 and from NASA Exobiology Award NAG5-12360 to D.H.B.

Received April 25, 2006; accepted June 27, 2006.

\section{REFERENCES}

Bevilacqua, P.C. 2003. Mechanistic considerations for general acidbase catalysis by RNA: Revisiting the mechanism of the hairpin ribozyme. Biochemistry 42: 2259-2265.

Bevilacqua, P.C., Brown, T.S., Nakano, S., and Yajima, R. 2004. Catalytic roles for proton transfer and protonation in ribozymes. Biopolymers 73: 90-109.

Bevilacqua, P.C., Brown, T.S., Chadalavada, D., Lecomte, J., Moody, E., and Nakano, S. 2005. Linkage between proton binding and folding in RNA: Implications for RNA catalysis. Biochem. Soc. Trans. 33: 466-470.

Blount, K.E. and Uhlenbeck, O.C. 2005. The structure-function dilemma of the hammer head ribozyme. Annu. Rev. Biophys. Biomol. Struct. 34: 415-440.

Canny, M.D., Jucker, F.M., Kellogg, E., Khvorova, A., Jayasena, S.D., and Pardi, A. 2004. Fast cleavage kinetics of a natural hammerhead ribozyme. J. Am. Chem. Soc. 126: 10848-10849.

Collins, R.A. 2002. The Neurospora Varkud satellite ribozyme. Biochem. Soc. Trans. 30: 1122-1126.

Dahm, S.C. and Uhlenbeck, O.C. 1991. Role of divalent metal-ions in the hammerhead RNA cleavage reaction. Biochemistry 30: 9464-9469.

Dahm, S.C., Derrick, W.B., and Uhlenbeck, O.C. 1993. Evidence for the role of solvated metal hydroxide in the hammerhead cleavage mechanism. Biochemistry 32: 13040-13045. 
De la Pena, M., Gago, S., and Flores, R. 2003. Peripheral regions of natural hammerhead ribozymes greatly increase their self-cleavage activity. EMBO J. 22: 5561-5570.

Dunham, C.M., Murray, J.B., and Scott, W.G. 2003. A helical twistinduced conformational switch activates cleavage in the hammerhead ribozyme. J. Mol. Biol. 332: 327-336.

Fedor, M.J. and Williamson, J.R. 2005. The catalytic diversity of RNAs. Nat. Rev. Mol. Cell Biol. 6: 399-412.

Guo, H.C.T. and Collins, R.A. 1995. Efficient trans-cleavage of a stemloop RNA substrate by a ribozyme derived from neurospora VS RNA. EMBO J. 14: 368-376.

Hampel, K.J. and Burke, J.M. 2003. Solvent protection of the hammerhead ribozyme in the ground state: Evidence for a cationassisted conformational change leading to catalysis. Biochemistry 42: 4421-4429.

Han, J. and Burke, J.M. 2005. Model for general acid-base catalysis by the hammerhead ribozyme: $\mathrm{pH}$-activity relationships of G8 and G12 variants at the putative active site. Biochemistry 44: 78647870 .

Heckman, J.E., Lambert, D., and Burke, J.M. 2005. Photocrosslinking detects a compact, active structure of the hammerhead ribozyme. Biochemistry 44: 4148-4156.

Hunsicker, L.M. and DeRose, V.J. 2000. Activities and relative affinities of divalent metals in unmodified and phosphorothioate-substituted hammerhead ribozymes. J. Inorg. Biochem. 80: 271-281.

Jones, F.D. and Strobel, S.A. 2003. Ionization of a critical adenosine residue in the Neurospora Varkud Satellite ribozyme active site. Biochemistry 42: 4265-4276.

Khvorova, A., Lescoute, A., Westhof, E., and Jayasena, S.D. 2003. Sequence elements outside the hammerhead ribozyme catalytic core enable intracellular activity. Nat. Struct. Biol. 10: 708-712.

Maderia, M., Hunsicker, L.M., and DeRose, V.J. 2000. Metalphosphate interactions in the hammerhead ribozyme observed by P-31 NMR and phosphorothioate substitutions. Biochemistry 39: 12113-12120.

Murray, J.B., Seyhan, A.A., Walter, N.G., Burke, J.M., and Scott, W.G. 1998. The hammerhead, hairpin and VS ribozymes are catalytically proficient in monovalent cations alone. Chem. Biol. 5: 587-595.

Nakano, S. and Bevilacqua, P.C. 2001. Proton inventory of the genomic HDV ribozyme in $\mathrm{Mg}(2+)$-containing solutions. J. Am. Chem. Soc. 123: 11333-11334.

Nakano, S., Cerrone, A.L., and Bevilacqua, P.C. 2003. Mechanistic characterization of the HDV genomic ribozyme: Classifying the catalytic and structural metal ion sites within a multichannel reaction mechanism. Biochemistry 42: 2982-2994.
Nesbitt, S., Hegg, L.A., and Fedor, M.J. 1997. An unusual pHindependent and metal-ion-independent mechanism for hairpin ribozyme catalysis. Chem. Biol. 4: 619-630.

Penedo, J.C., Wilson, T.J., Jayasena, S.D., Khvorova, A., and Lilley, D.M. 2004. Folding of the natural hammerhead ribozyme is enhanced by interaction of auxiliary elements. RNA 10: 880-888.

Pinard, R., Hampel, K.J., Heckman, J.E., Lambert, D., Chan, P.A., Major, F., and Burke, J.M. 2001. Functional involvement of G8 in the hairpin ribozyme cleavage mechanism. EMBO J. 20: 64346442.

Pley, H.W., Flaherty, K.M., and McKay, D.B. 1994. Three-dimensional structure of a hammerhead ribozyme. Nature 372: 68-74.

Raines, R.T. 1998. Ribonuclease A. Chem. Rev. 98: 1045-1066.

Saksmerprome, V., Roychowdhury-Saha, M., Jayasena, S., Khvorova, A., and Burke, D.H. 2004. Artificial tertiary motifs stabilize transcleaving hammerhead ribozymes under conditions of submillimolar divalent ions and high temperatures. RNA 10: 1916-1924.

Scott, W.G., Finch, J.T., and Klug, A. 1995. The crystal structure of an all-RNA hammerhead ribozyme: A proposed mechanism for RNA catalytic cleavage. Cell 81: 991-1002.

Takagi, Y., Warashina, M., Stec, W.J., Yoshinari, K., and Taira, K. 2001. Recent advances in the elucidation of the mechanisms of action of ribozymes. Nucleic Acids Res. 29: 1815-1834.

Tuschl, T., Gohlke, C., Jovin, T.M., Westhof, E., and Eckstein, F. 1994 A three-dimensional model for the hammerhead ribozyme based on fluorescence measurements. Science 266: 785-789.

Vogt, M., Hunsicker, L., Cosper, N., Scott, R., and DeRose, V.J. 2003. Spectroscopic probes for metals and catalysis in the hammerhead ribozyme. Biophys. J. 84: 180A-181A.

Wang, S.L., Karbstein, K., Peracchi, A., Beigelman, L., and Herschlag, D. 1999. Identification of the hammerhead ribozyme metal ion binding site responsible for rescue of the deleterious effect of a cleavage site phosphorothioate. Biochemistry 38: 1436314378.

Wedekind, J.E. and McKay, D.B. 1998. Crystallographic structures of the hammerhead ribozyme: Relationship to ribozyme folding and catalysis. Annu. Rev. Biophys. Biomol. Struct. 27: 475-502.

Yen, L., Svendsen, J., Lee, J.S., Gray, J.T., Magnier, M., Baba, T., D'Amato, R.J., and Mulligan, R.C. 2004. Exogenous control of mammalian gene expression through modulation of RNA selfcleavage. Nature 431: 471-476.

Zamel, R., Poon, A., Jaikaran, D., Andersen, A., Olive, J., De Abreu, D., and Collins, R.A. 2004. Exceptionally fast self-cleavage by a Neurospora Varkud satellite ribozyme. Proc. Natl. Acad. Sci. 101: $1467-1472$. 

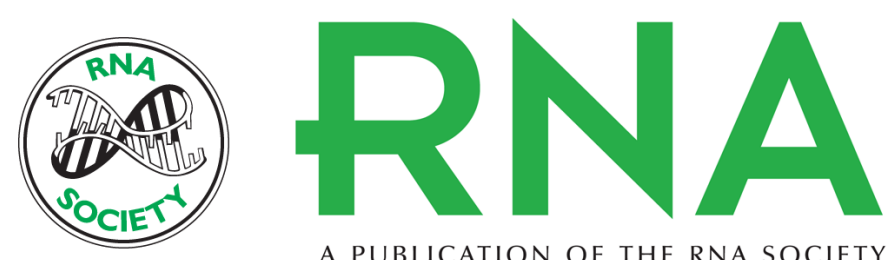

A PUBLICATION OF THE RNA SOCIETY

\section{Extraordinary rates of transition metal ion-mediated ribozyme catalysis}

Manami Roychowdhury-Saha and Donald H. Burke

RNA 2006 12: 1846-1852

References This article cites 36 articles, 6 of which can be accessed free at:

http://rnajournal.cshlp.org/content/12/10/1846.full.html\#ref-list-1

License

Email Alerting Receive free email alerts when new articles cite this article - sign up in the box at the Service top right corner of the article or click here.

To subscribe to RNA go to:

http://rnajournal.cshlp.org/subscriptions 